\title{
Last snails standing since the Early Pleistocene, a tale of Calliostomatidae (Gastropoda) living in deep-water coral habitats in the north-eastern Atlantic
}

\author{
LEON HOFFMAN ${ }^{1,4}$, LYDIA BEUCK ${ }^{1}$, BART VAN HEUGTEN ${ }^{1}$, \\ MARC LAVALEYE ${ }^{2} \&$ ANDRÉ FREIWALD ${ }^{1,3}$ \\ ${ }^{1}$ Marine Research Department, Senckenberg am Meer, Südstrand 40, Wilhelmshaven, Germany \\ ${ }^{2}$ NIOZ Royal Netherlands Institute for Sea Research, and Utrecht University, Texel, Netherlands \\ ${ }^{3}$ MARUM, Bremen University, Leobener Strasse 8, Bremen, Germany \\ ${ }^{4}$ Corresponding author. E-mail: Leon.Hoffman@Senckenberg.de
}

\begin{abstract}
Three species in the gastropod genus Calliostoma are confirmed as living in Deep-Water Coral (DWC) habitats in the NE Atlantic Ocean: Calliostoma bullatum (Philippi, 1844), C. maurolici (Seguenza, 1876) and C. leptophyma Dautzenberg \& Fischer, 1896. Up to now, C. bullatum was only known as fossil from Early to Mid-Pleistocene outcrops in DWC-related habitats in southern Italy; our study confirmed its living presence in DWC off Mauritania. A discussion is provided on the distribution of DWC-related calliostomatids in the NE Atlantic and the Mediterranean Sea from the Pleistocene to the present.
\end{abstract}

Key words: Mollusca, Calliostoma, deep-water coral associations, NE Atlantic Ocean, Mediterranean Sea, systematics

\section{Introduction}

The Senckenberg Institute and the Royal Netherlands Institute for Sea Research (NIOZ) investigate the geophysical, geological and biological characteristics of scleractinian-dominated Deep-Water Coral (DWC) habitats in the world. The north-eastern Atlantic Ocean has been a focus area and the current article is a spin-off of the biodiversity investigations in this region.

DWCs are commonly found along the continental slopes of all oceans and they occur from less than $100 \mathrm{~m}$ depth in colder regions to more than $1000 \mathrm{~m}$ in more moderate temperature regions (Rogers 1999) and shallowing up to 400-660 m off north-western Africa (Westphal et al. 2014; Ramos et al. 2017). These DWC habitats can develop into three-dimensional topographically well-defined reef structures, which influence the bottom current regime. Prerequisites for the presence of thriving DWC are a suitable range of water temperature, dissolved oxygen level, access to suspended food, a substrate and adequate sedimentation rate. Once a DWC habitat is established, they often quickly monopolise the seabed and eventually form self-sustaining reefs over time. If several fossil reefal episodes are stacked in one place over time, geologists speak of coral mounds (Roberts et al. 2006). Larger mound complexes measure 100-350 m in height and several tens to hundreds of kilometres in lateral extension (Rogers 1999; Roberts et al. 2006; Wheeler et al. 2007; Ramos et al. 2017).

Live and dead DWC framework provides a broad suite of microhabitats for other organisms. This habitat heterogeneity is a major attractor for a species and often biomass-rich community (Buhl-Mortensen et al. 2010). In an ongoing census of the DWC-associated fauna, more than 10.000 species have been reported from several hundred taxonomic publications starting from the famous H.M.S. Challenger expeditions to the present (Freiwald, unpublished). Our own research is focused on the shelly molluscs in the temperate and tropical North Atlantic, which has yielded about 1.600 mollusc species from approximately 280 stations from DWC settings held by NIOZ and Senckenberg Institutions. The geographic spread of these stations ranges from northern Norway $\left(71^{\circ} \mathrm{N}\right)$ as far south as to Mauritania $\left(17^{\circ} \mathrm{N}\right)$ with major study areas in the Oslofjord-Kosterfjord, Mingulay, Hatton Bank, Rockall Bank, Porcupine Bank, Celtic margin, Galicia Bank, Atlantic Morocco and Mauritania. 
This study is based on collection campaigns during cruises held since 1997 (Table 1). These campaigns include geophysical mapping of the sea bottom and its subsurface to high-grade potential areas where DWC-habitats could be expected. When feasible, video data were gathered either by a towed camera, a lander or by Remotely Operated Vehicle (ROV), often complemented with actual sampling by a ROV or a video-guided box corer. Records from ROV stations are listed herein with coordinates and depth at starting point of dive. In addition, bottom samples were taken by using a ROV manipulator, van Veen grab, box corer or dredge. The live material collected by a ROV or using other sampling methods was preserved, mostly in ethanol. The remaining sediment with biological remains was rinsed with fresh water, dried, and retained for further analysis. The alcohol collection and sediment samples were studied as part of the biodiversity inventory efforts for the Mollusca.

TABLE 1. Cruises referred in this study, with related station data specified in the cruise reports.

\begin{tabular}{|c|c|c|c|c|}
\hline Cruise & Year & Research Vessel & Area & Reference \\
\hline VH97 & 1997 & Victor Hensen & Galicia Bank & $\begin{array}{l}\text { Freiwald \& Henrich } \\
\text { (1997) }\end{array}$ \\
\hline POS265 & 2000 & Poseidon & Porcupine Seabight & Freiwald \& Dullo (2000) \\
\hline CARACOLE & 2001 & L'Atalante & Porcupine Bank and Seabight & Olu-Le Roy et al. (2002) \\
\hline POS292 & 2002 & Poseidon & $\begin{array}{l}\text { W Rockall Bank and Porcupine } \\
\text { Seabight }\end{array}$ & Freiwald (2002) \\
\hline ARK-XIX-3a PS64 & 2003 & Polarstern & Porcupine Bank and Seabight & Thiede (2003) \\
\hline M61-1 & 2004 & Meteor & Porcupine Seabight & Pfannkuche et al. (2004) \\
\hline M61-3 & 2004 & Meteor & $\begin{array}{l}\text { W Rockall Bank and Porcupine } \\
\text { Bank and Seabight }\end{array}$ & Ratmeyer et al. (2004) \\
\hline POS316 & 2005 & Poseidon & $\begin{array}{l}\text { W Rockall Bank and Porcupine } \\
\text { Seabight }\end{array}$ & $\begin{array}{l}\text { Pfannkuche \& Utecht } \\
\text { (2005) }\end{array}$ \\
\hline $\begin{array}{l}\text { HERMES2006 } \\
64 \text { PE249 }\end{array}$ & 2006 & Pelagia & SE Rockall Bank & Duineveld (2006) \\
\hline POS346 & 2007 & Poseidon & Mauritanian Slope & Westphal (2007) \\
\hline 64PE284 & 2008 & Pelagia & Gulf of Cadiz & Hebbeln et al. (2008) \\
\hline $\begin{array}{l}\text { HERMES } 2008 \\
64 P E 291 / 292\end{array}$ & 2008 & Pelagia & Hatton Bank & Lavaleye (2008) \\
\hline MSM16-3 & 2010 & Maria S. Merian & Mauritanian Slope & Westphal et al. (2014) \\
\hline POS400 & 2010 & Poseidon & Porcupine Seabight & Wienberg et al. (2010) \\
\hline M151 & 2018 & Meteor & $\begin{array}{l}\text { Azores and South Azorean } \\
\text { Seamount Chain }\end{array}$ & Frank (2018) \\
\hline
\end{tabular}

We selected three species representing the genus Calliostoma (Gastropoda) for this publication because the use of combined ROV footage, selected species sampling and bulk sediment sampling has led to unique insights about these species; the adult shells of the three species are large enough to be identified on video material especially from underwater high-definition cameras.

The Mollusca wet-collection (in ethanol, 96\% plus 1\% methyl ethyl ketone) and part of the dry material are stored at Senckenberg am Meer in Wilhelmshaven, Germany. Dried specimens are also stored at Naturalis in Leiden, the Netherlands.

\author{
Abbreviations \\ DWC Deep-Water Coral \\ GeoB Unique sampling station code of Bremen University, Germany \\ $\mathrm{H} \quad$ Height of specimen \\ MNHN National Museum of Natural History, Paris, France \\ NIOZ Royal Netherlands Institute for Sea Research, Texel, Netherlands \\ ROV Remotely Operated Vehicle \\ SaM Senckenberg am Meer, Wilhelmshaven, Germany \\ $\mathrm{T} \quad$ Thickness (minimum diameter) of specimen \\ W Width (maximum diameter) of specimen
}




\section{Systematics}

The family Calliostomatidae Thiele, 1924 (Trochoidea, Vetigastropoda, Gastropoda) has been reconfirmed as a distinct family by molecular studies (Williams et al. 2008, 2010; Williams 2012). Even though the family currently comprises about 29 extant genera, the genus Calliostoma takes the lion's share in species; all calliostomatids in the NE Atlantic are placed in Calliostoma. A generic classification was carried out for calliostomatids from New Zealand (Marshall 1995a) and New Caledonia, the Loyalty Islands, and the northern Lord Howe Rise (Marshall 1995b). The historic generic subdivision of NE Atlantic and Mediterranean calliostomatids was largely based on shell morphology; it was abandoned in the $20^{\text {th }}$ century; all genera are currently lumped under Calliostoma. A generic revision of these species is required but this effort is beyond the scope of this study.

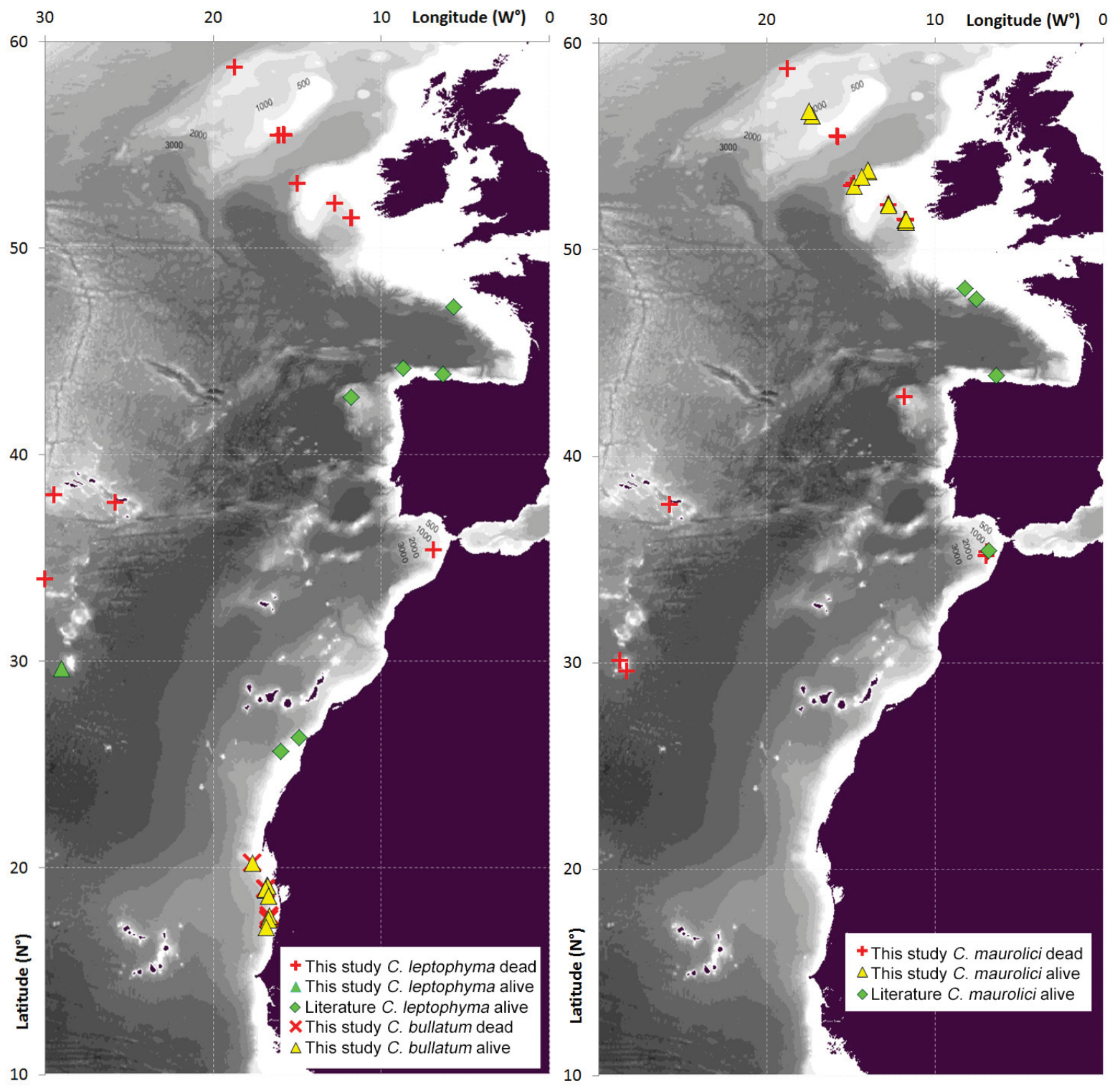

FIGURE 1. Distribution maps of Calliostoma bullatum and Calliostoma leptophyma (left) and of Calliostoma maurolici (right). In the left map, empty shells of Calliostoma bullatum as red diagonal crosses, live observations as yellow triangles, empty shells of Calliostoma leptophyma as red normal crosses, live observations in this study as green triangles, live observations from literature as green diamonds. In the right map, empty shells of Calliostoma maurolici as red normal crosses, live observations as yellow triangles, live observations from literature as green diamonds. Bathymetry data source: GEBCO, depth contour intervals $500 \mathrm{~m}$. 


\section{Genus Calliostoma Swainson, 1840}

Type species. Trochus conulus Linnaeus, 1758 now accepted as Calliostoma conulus (Linnaeus, 1758).

Comments. Most species in Calliostoma are carnivore (Fretter \& Graham 1977; Perron \& Turner 1978; Quinn 1981; Ferro \& Cretella 1993; Marshall 1995a, b; Harasewych \& Sedberry 2006; Williams et al. 2010; Dornellas \& Simone 2011; de Bruyne et al. 2013). Calliostoma zizyphinum (Linnaeus, 1758) from the continental slopes of the NE Atlantic and the Mediterranean Sea also feeds on plant material as a minor part of its diet (Fretter \& Graham 1977; de Bruyne et al. 2013).

This paper concentrates on three species that have been commonly recorded from framework-building DWC habitats in the NE Atlantic during our studies: Calliostoma bullatum (Philippi, 1844), C. maurolici (Seguenza, 1876) and C. leptophyma Dautzenberg \& Fischer, 1896. Other species have been reported from DWC locations in the NE Atlantic but they are not discussed here because they have not, or only scarcely, been encountered in our study areas: C. caroli Dautzenberg 1927, C. cleopatra (Locard, 1898), C. granulatum (Born, 1778), C. grimaldii Dautzenberg \& H. Fischer, 1896, C. hirondellei Dautzenberg \& H. Fischer, 1896, C. lividum Dautzenberg 1927, C. normani (Dautzenberg \& H. Fischer, 1897) and C. occidentale (Mighels \& C. B. Adams, 1842).

\section{Calliostoma bullatum (Philippi, 1844)}

(Figs 2-20)

Trochus bullatus Philippi, 1844: 226, tab. 28, fig. 8

Calliostoma bullatum: Barrier et al. (1996): 43

Calliostoma bullatum: La Perna \& D'Abramo, 2010: 31-34, fig. 2A-D

Type material. The whereabouts of the type material is unknown; it is not in the Museum für Naturkunde-Leibniz-Institut für Evolutions- und Biodiversitätsforschung, Berlin, where part of the Philippi collection is retained. Philippi (1844) reported Calliostoma bullatum from Calabrian (0.8-1.8 Ma, Early Pleistocene) outcrops near Messina, Sicily. A neotype needs to be designated, preferentially a topotype.

Material. Mauritania, Tanoûdêrt Canyon, MSM16-3/GeoB 14796 (ROV3), $20.247^{\circ} \mathrm{N}, 17.670^{\circ} \mathrm{W}, 642 \mathrm{~m}$, live individuals observed, 03-XI-2010; MSM16-3/GeoB $14799,20.243^{\circ} \mathrm{N}, 17.668^{\circ} \mathrm{W}, 490 \mathrm{~m}$, three shells, grab, 03-XI2010; MSM16-3/GeoB 14801, 20.246 $\mathrm{N}, 17.670^{\circ} \mathrm{W}, 568 \mathrm{~m}$, one shell, grab, 04-XI-2010;

Nouamghar Canyon, MSM16-3/GeoB 14779 (ROV2) $19.180^{\circ} \mathrm{N}, 16.806^{\circ} \mathrm{W}, 618 \mathrm{~m}$, live individuals observed, 30-X-2010.

Inchiri Canyon, MSM16-3/GeoB 14871 (ROV4) $19.139^{\circ} \mathrm{N}, 16.764^{\circ} \mathrm{W}, 566 \mathrm{~m}$, live individuals observed, 09XI-2010; MSM16-3/GeoB 14871 (ROV5) $19.139^{\circ} \mathrm{N}, 16.765^{\circ} \mathrm{W}, 588 \mathrm{~m}$, live individuals observed, 2 specimens collected and retained in ethanol, 09-XI-2010.

Timiris Mound Complex, MSM16-3/GeoB 14873 (ROV7), $18.951^{\circ} \mathrm{N}, 16.875^{\circ} \mathrm{W}, 485-574 \mathrm{~m}$, live individuals on live sponges observed, 10-XI-2010; MSM16-3/GeoB $14876,18.962^{\circ} \mathrm{N}, 16.870^{\circ} \mathrm{W}, 548 \mathrm{~m}$, two shells, box corer, 12-XI-2010; MSM16-3/GeoB 14877, $18.963^{\circ} \mathrm{N}, 16.869^{\circ} \mathrm{W}, 498 \mathrm{~m}, 13$ shells, box corer, 12-XI-2010; POS346/GeoB $11587,18.983^{\circ} \mathrm{N}, 16.866^{\circ} \mathrm{W}, 482 \mathrm{~m}$, one shell, box corer, 09-I-2007; POS346/GeoB $11588,18.983^{\circ} \mathrm{N}, 16.864^{\circ} \mathrm{W}$, $474 \mathrm{~m}$, nine shells, box corer, 09-I-2007.

Tioulit Canyon, MSM16-3/GeoB 14886 (ROV8), $18.650^{\circ} \mathrm{N}, 16.726^{\circ} \mathrm{W}, 640 \mathrm{~m}$, live individuals observed, $12-$ XI-2010; MSM16-3/GeoB 14891 (ROV9), $18.664^{\circ} \mathrm{N}, 16.724^{\circ} \mathrm{W}, 592 \mathrm{~m}$, live individuals observed, 13-XI-2010.

Banda Mound Complex, POS346/GeoB 11564, $17.646^{\circ} \mathrm{N}, 16.666^{\circ} \mathrm{W}, 442 \mathrm{~m}, 10$ shells, box corer, 07-I-2007; POS346/GeoB $11567,17.659^{\circ} \mathrm{N}, 16.668^{\circ} \mathrm{W}, 428 \mathrm{~m}$, eight shells, box corer, 07-I-2007; POS346/GeoB 11568, $17.664^{\circ} \mathrm{N}, 16.673^{\circ} \mathrm{W}, 514 \mathrm{~m}$, six shells, box corer, 08-I-2007; POS346/GeoB $11569,17.667^{\circ} \mathrm{N}, 16.672^{\circ} \mathrm{W}, 440 \mathrm{~m}$, 17 shells, box corer, 08-I-2007; POS346/GeoB $11578,17.675^{\circ} \mathrm{N}, 16.670^{\circ} \mathrm{W}, 458 \mathrm{~m}$, eight shells, box corer, 08-I2007; POS346/GeoB 11579, $17.679^{\circ} \mathrm{N}, 16.668^{\circ} \mathrm{W}, 450 \mathrm{~m}$, two shells, box corer, 08-I-2007, (Figs 2-5); POS346/ GeoB $11580,17.684^{\circ} \mathrm{N}, 16.668^{\circ} \mathrm{W}, 481 \mathrm{~m}$, three shells, box corer, 08-I-2007; MSM16-3/GeoB 14908 (ROV11), $17.670^{\circ} \mathrm{N}, 16.681^{\circ} \mathrm{W}, 574 \mathrm{~m}$, live individuals observed, $16-\mathrm{XI}-2010$.

Tamxat Mound Complex, MSM16-3/GeoB 14902 (ROV10), $17.540^{\circ} \mathrm{N}, 16.668^{\circ} \mathrm{W}, 580 \mathrm{~m}$, live individuals observed, 15-XI-2010; MSM16-3/GeoB 14903, $17.548^{\circ} \mathrm{N}, 16.662^{\circ} \mathrm{W}, 414 \mathrm{~m}$, three shells, box corer, 15-XI-2010; 
MSM16-3/GeoB $14904,17.543^{\circ} \mathrm{N}, 16.663^{\circ} \mathrm{W}, 510 \mathrm{~m}$, eight shells, box corer, 15-XI-2010; MSM16-3/GeoB 14905, $17.541^{\circ} \mathrm{N}, 16.667^{\circ} \mathrm{W}, 486 \mathrm{~m}$, two shells, box corer, $15-\mathrm{XI}-2010$; MSM16-3/GeoB $14910,17.483^{\circ} \mathrm{N}, 16.694,535^{\circ} \mathrm{W}$ $\mathrm{m}$, one shell, box corer, 16-XI-2010; MSM16-3/GeoB 14911, $17.482^{\circ} \mathrm{N}, 16.692^{\circ} \mathrm{W}, 450 \mathrm{~m}, 2$ live juveniles dried, box corer, 16-XI-2010.

Tiguent Mound Complex, MSM16-3/GeoB 14914 (ROV12), $17.137^{\circ} \mathrm{N}, 16.825^{\circ} \mathrm{W}, 514 \mathrm{~m}$, live individuals observed, 17-XI-2010.

Description by Philippi (1844). Trochus Testa tenui, late et convexo-conica; anfractibus convexis, sutura satis profunda distinctis, sulcis circa sex, latissimis, superficialibus sculptis, ultimo obtuse angulato; basi ad columellam striata, caeterum laevi. [Shell thin, wide, convex-conical; whorls convex, with rather deep suture, and about six very wide shallow grooves, the last whorl with a blunt keel; the base with striae near columella, the rest smooth]

Testa 15" alta, 15" lata et major, primo adspectu Tr. Granulato simillima sed distinctissima. Forma multo latior, convexo conica, non concavo-conica; anfractus convexiusculi, non marginati, laevissimi, minime granulate, ultimus longe magis rotundatus; basis laevissima praeter sulcus seu strias 4 columellam cingentes. [Shell with a height of 15 lines $(34 \mathrm{~mm})$ and maximal width of 15 lines $(34 \mathrm{~mm})$, similar but distinct from Tr. Granulato (now Calliostoma granulatum). Form much broader, convex-conical, not concave-conical; whorls convex, rounded, smooth, with minimal granulation, the last whorl more rounded; basis smooth with 4 spiral grooves]

Additional description. Adult specimen with about seven slightly convex whorls (excluding protoconch). Teleoconch whorls with fine spiral striation, spire conical with slightly convex outline (Figs 6-8). Top angle of spire about $65^{\circ}$. Base flattened. Height of the largest specimen $36 \mathrm{~mm}$, width $36 \mathrm{~mm}$ (Fig. 6).
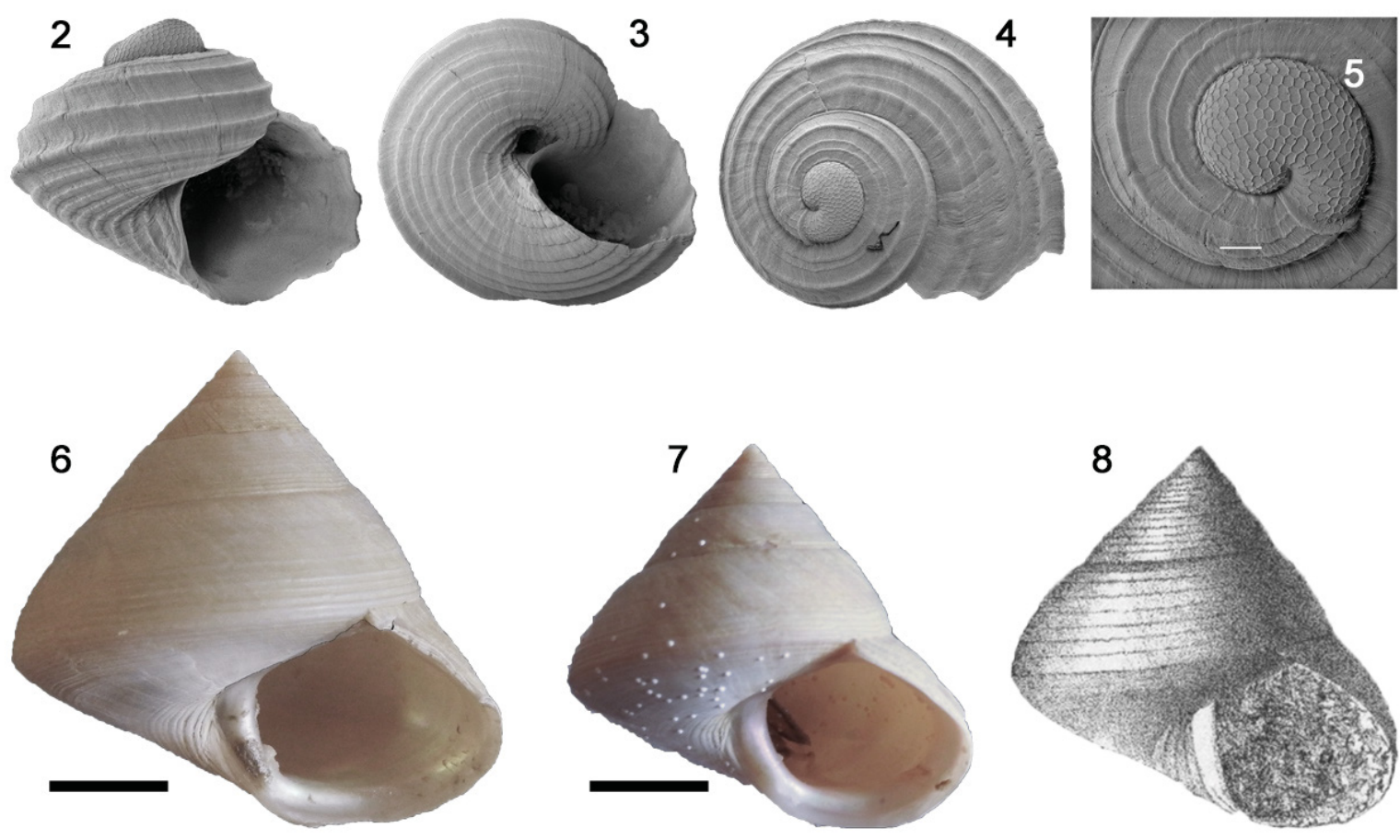

FIGURES 2-8. Calliostoma bullatum, 2-5. POS346/ GeoB 11579, 2-3. H 1.4 mm, W 1.7 mm. 4-5. W 2.0 mm, T 1.6 mm, protoconch W $0.47 \mathrm{~mm}$, T $0.35 \mathrm{~mm}$, scale bar $0.1 \mathrm{~mm}$. 6-7. MSM16-3/ GeoB 14871, live-collected, scale bars $10 \mathrm{~mm}, 6 . \mathrm{H} 36$ mm, W $36 \mathrm{~mm}$. 7. H $31 \mathrm{~mm}$, W $32 \mathrm{~mm}$. 8. Trochus bullatus, original illustration by Philippi (1844), H $34 \mathrm{~mm}$, W $34 \mathrm{~mm}$.

Protoconch swollen, 0.8 whorls, with hexagonal-reticulated sculpture on smooth background, reticulated cells about $0.02 \mathrm{~mm}$ diameter (Fig. 5). Varix at transition to teleoconch rounded, prosocyrt. Size 0.47 x $0.35 \mathrm{~mm}$.

First teleoconch whorl convex with five rounded spiral ribs above periphery; shoulder area flattened with weaker spiral ribs (Figs 2-4). Base of first teleoconch whorl with nine, broad-flattened ribs and narrow, open umbilicus. Aperture angular, columella convex, inner shell nacreous. Outer lip of a juvenile blunt, prosocline at about $25^{\circ}$ with shell axis. After 2 teleoconch whorls, outline more flattened; whorls with 6-14 spiral ribs which are finer, more numerous and evenly distributed; additional spiral ribs emerge as thin threads between two stronger ones. 
Spiral ribs stronger near the periphery on whorls six and seven; fine beads frequently present on the first and second spiral rib below the suture in the first whorls. Body whorl slightly more convex with blunt keel at periphery. Some specimens show slightly more convex whorls and a more regular pattern of fine spiral ribs on the whorl face. Base flattened with spiral ribs that are strongly developed near periphery and near columella. Umbilicus closed in adult specimens. Aperture angular and inside of the shell smooth and nacreous, columella convexly curved and its callus clearly demarcates the transition to the external shell. Lip blunt, strongly prosocline under $45^{\circ}$ with shell axis. Colour cream white with a nacreous shine; periostracum absent (Figs 6-8).

Head white, centrally swollen, snout wide oblong with thin necklobes; necklobe rectangular at the front; lobes pinkish posteriorly (Fig. 9). Two long pointed cephalic tentacles, greyish at tips. Eyes black, situated on short ommatophores behind base of cephalic tentacles. Foot muscular with remarkable ability to adapt to rugose and variable substrates (Fig. 11). Back of the foot with wide dorsal groove (Fig. 10). At least four epipodial sensory tentacles on either side in dorsal position, emerging between shell and foot (Figs 9-12). Base of foot with wide edge corrugated up front (Fig. 9). Operculum circular, spirally developed, brown translucent, thin, chitinous.

Distribution. Calliostoma bullatum is commonly found as fossil in Early to Mid-Pleistocene formations that were deposited in bathyal depths in association with remains of the colonial Lophelia pertusa (Linnaeus, 1758) and Madrepora oculata Linneaus, 1758 (Barrier et al. 1996; La Perna \& D’Abramo 2010). The fossil record suggests that this species has been living for about 2.5 million years.

Recent including living specimens have only been from off Mauritania in DWC habitats, dead at 414-588 m, alive at 450-642 m (Fig. 1). The species is unknown from Morocco's Atlantic Margin or from the Lusitanian islands or seamounts. It is possible that the species is living further south along the African shelf as DWC habitats along this coast are poorly sampled.

Remarks. Our findings are the first living records of this species that up to now was only known as fossil. They resemble Philippi's (1844) figure very well (Fig. 8) especially on size, outline, the incremental convexity of the body whorl, shape of the aperture, development of the columellar callus and the sculpture on the base of the body whorl, particularly that near the columella. Philippi (1844) mentioned about six spiral grooves. Fossil specimens from Sicily have 6-10 grooves or ribs on the body whorl. Specimens from Mauritania show typically 10-14 ribs. We consider this difference variability within the species. Variability of spiral rib sculpture is common in calliostomatids, for example in the European species Calliostoma zizyphinum (Cossignani \& Ardovini 2011) and in several species in Maurea from New Zealand (Marshall 1995a).

Calliostoma bullatum is the largest representative of the genus in the NE Atlantic and the Mediterranean Sea. Calliostoma bullatum Coen 1933 (non Philippi, 1844) is a synonym of Calliostoma conulus. The deep-water species Calliostoma maurolici (G. Seguenza, 1876) will be discussed in the following; it is smaller, with a stronger spiral ornament, more convex whorls, a wider top angle and an open umbilicus when adult. Calliostoma cleopatra (Locard, 1898 ) is another deep-water species described from off Western Sahara at 1035-1056 m; it is smaller, with more convex whorls, stronger spiral sculpture and stronger beads on the top spiral ribs. Calliostoma caroli Dautzenberg 1927 was described from the Azores at $1250 \mathrm{~m}$; it has a more angular outline with a stronger spiral structure, and it is smaller than our species. Calliostoma leptophyma Dautzenberg \& H. Fischer, 1896 will be discussed below; it is similar to Calliostoma cleopatra but it lacks the strong carinae on the ribs and it has a more compressed outline. Calliostoma normani (Dautzenberg \& H. Fischer, 1897) is described from the Azores at $1600 \mathrm{~m}$; it is similar to $C$. caroli but has finer spiral ribs, inflated whorls and lacks a blunt keel. We also considered other Western and Eastern Atlantic calliostomatids but we did not find a match with our specimens; all have either a stronger spiral (beaded) structure, are smaller or show a stronger keel. Interestingly, live and dead scleractinian corals were found in all above cited dredge hauls together with the calliostomatids.

We observed this species with ROV surveys on various live fauna: Porifera (Figs 15-16), Hydrozoa (Fig. 9), Scleractinia (Figs 10-14), Octocorallia (Fig. 20), and Mollusca (Figs 17-20). It appears to be preferentially feeding on soft tissue of Lophelia pertusa, Madrepora oculata, epibionts and rarely on other tissue e.g., of Cladorhiza corallophila Göcke et al., 2016. We have retained the two specimens in ethanol for future study at Senckenberg am Meer, Wilhelmshaven (SaMID1435, SaMID1516). 

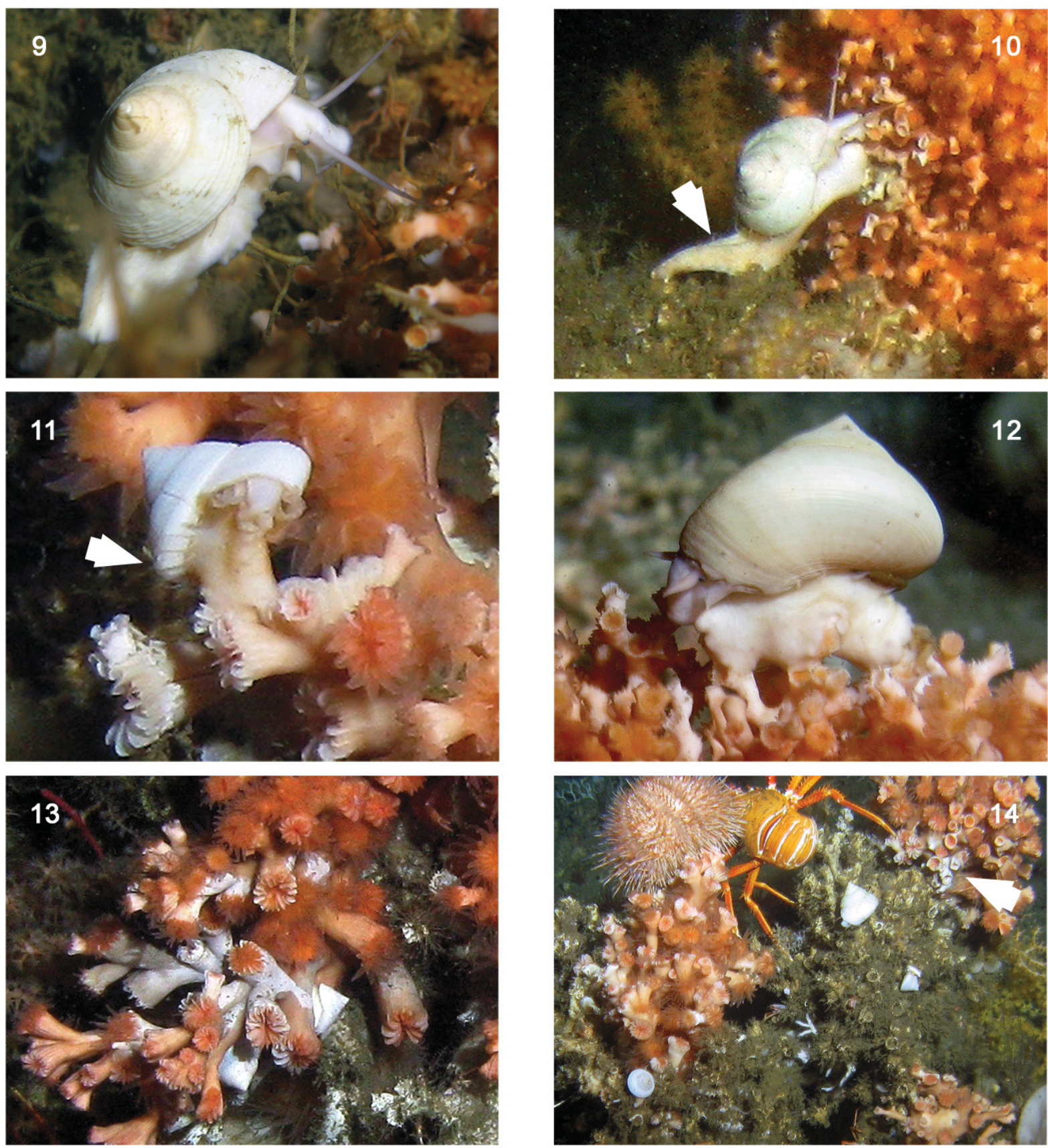

FIGURES 9-14. Calliostoma bullatum on various substrates. 9. MSM16-3/GeoB 14871 (ROV4). Grazing on hydroids. 10. MSM16-3/GeoB 14871 (ROV4). Elongated, muscular foot supports feeding on polyp tissue (Madrepora oculata). Operculum and dorsal groove on foot indicated by arrow. 11. MSM16-3/GeoB 14873 (ROV7). Muscular foot enables elevation of body above substrate (live Lophelia pertusa). Epipodial sense organs spread directly below the shell (arrow). 12. MSM16-3/GeoB 14871 (ROV4). Feeding on apical portions of a live Madrepora oculata. 13. MSM16-3/GeoB 14779 (ROV2). Two individuals feeding on Lophelia pertusa tissue; note the grazing tracks showing the bare, white coral skeleton devoid of polyp tissue in contrast to the orange to pale-pinkish live portions. 14. MSM16-3/GeoB 14891 (ROV9). Three individuals of different sizes all feeding on epibionts of Lophelia pertusa framework; note the grazing traces on adjacent live Lophelia pertusa portions (see arrow). [Figs 9-20 were taken by ROV “Sperre”, Tomas Lundälv, Sven Lovén Centre for Marine Infrastructure, Tjärnö, University of Gothenburg, Strömstad, Sweden]. 

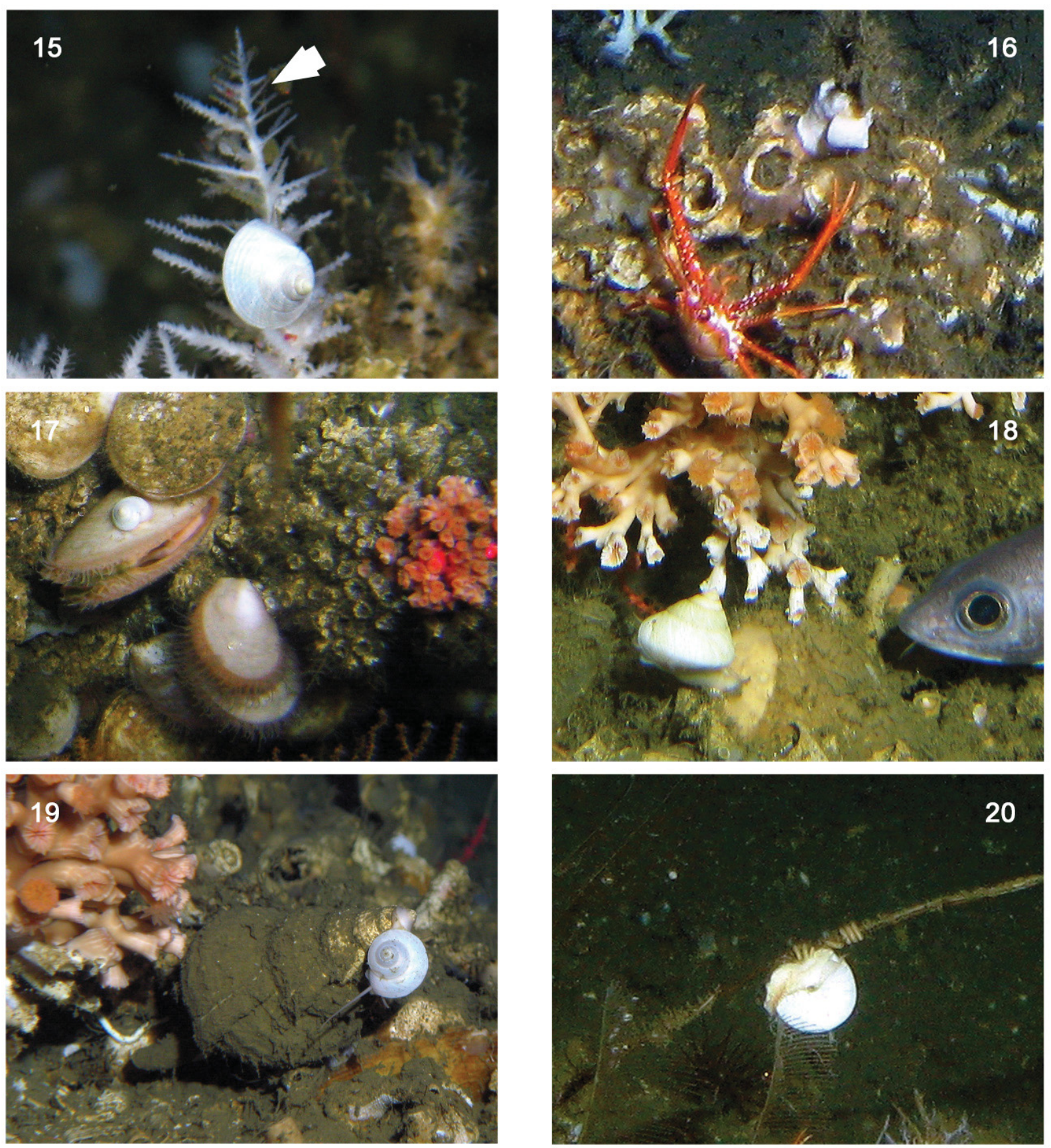

FIGURES 15-20. Calliostoma bullatum on substrates. 15. MSM16-3/GeoB 14871 (ROV5). Grazing on carnivorous sponge Cladorhiza corallophila; arrow indicating grazing effect. 16. MSM16-3/GeoB 14902 (ROV10). On framework encrusting sponge. 17. MSM16-3/GeoB 14902 (ROV10). Grazing on a valve of live Acesta excavata, which is colonised by epibionts; the two laser points are at a distance of $6 \mathrm{~cm}$. 18. MSM16-3/GeoB 14902 (ROV10). Grazing on a valve of dead Acesta excavata (note in direct surrounding the free portions of epibionts on the valve and the white framework portions of Lophelia pertusa lacking any tissue). 19. MSM16-3/GeoB 14902 (ROV10). Grazing on a gastropod shell (Ranella olearium). 20. MSM16-3/ GeoB 14891 (ROV9). Grazing on dead hydroid axis in close vicinity to a Solenogastres. 


\section{Calliostoma maurolici (G. Seguenza, 1876)}

(Figs. 21-34)

Trochus (Zizyphinus) maurolici G. Seguenza, 1876: 184

Gibbula obesula Locard, 1898: ex P. Fischer ms.; vol. 2, 47-49, pl. 3 figs 1-4

Gibbula maurolici: L. Seguenza 1903: 460-461, tab. XVII, fig. 17

Calliostoma maurolici: Micali \& Villari 1989: 350, 360-362, figs 9-11

Calliostoma maurolici: Di Geronimo \& La Perna 1997: 418, synonymised Gibbula obesula Locard, 1898

Type material. Type locality is a Calabrian (Early Pleistocene) outcrop near Messina, Sicily. The type material of Trochus maurolici is lost. Syntypes of Gibbula obesula from Atlantic Morocco, off Cape Spartel, are retained in MNHN: MNHN-IM-2000-31248, Talisman-1883-10, 717 m (Chagnoux 2017).

Material examined. Moroccan Slope, 64PE284/GeoB 12712, 35.368 $\mathrm{N}, 06.903^{\circ} \mathrm{W}, 685 \mathrm{~m}, 10$ shells in Pleistocene thanatocoenosis, grab, 23-II-2008; 64PE284/GeoB $12729,35.181^{\circ} \mathrm{N}, 06.942^{\circ} \mathrm{W}, 754 \mathrm{~m}, 18$ shells in Pleistocene thanatocoenosis, video box core, 26-II-2008.

Galicia Bank, VH97/61, $42^{\circ} 874^{\circ} \mathrm{N}, 11.823^{\circ} \mathrm{W}, 1080 \mathrm{~m}$; six shells in pteropod ooze, grab, 08-IV-1997.

Porcupine Basin, Belgica Mound Province, Therese Mound, CARACOLE/PL124-2, 51.431 ${ }^{\circ} \mathrm{N}, 11.754^{\circ} \mathrm{W}$, 807-1016 m, live individuals observed, 01-VIII-2001; PS64/278 (ROV), live individuals observed, $51.456^{\circ} \mathrm{N}$, $11.736^{\circ} \mathrm{W}, 992 \mathrm{~m}, 10-\mathrm{VI}-2003$; M61-1/245 (DOS Lander), live individual observed, $51.456^{\circ} \mathrm{N}, 11.753^{\circ} \mathrm{W}, 806$ m, 25-IV-2004; Galway Mound, M61-3/550 (GeoB 9203, ROV), 51.445 ${ }^{\circ} \mathrm{N}, 11.751^{\circ} \mathrm{W}, 892 \mathrm{~m}$, live individuals observed, 05-VI-2004; M61-3/552 (GeoB 9205), $51.451^{\circ} \mathrm{N}, 11.752^{\circ} \mathrm{W}, 810 \mathrm{~m}$, one shell, box corer, 02-VI-2004; POS316/528, $51.438^{\circ} \mathrm{N}, 11.740^{\circ} \mathrm{W}, 916 \mathrm{~m}$, one shell, box corer, 11-VIII-2004; Poseidon Mound, M61-3/575 (GeoB 9228), $51.462^{\circ} \mathrm{N}, 11.693^{\circ} \mathrm{W}, 752 \mathrm{~m}$, one shell, box corer, 07-VI-2004; POS292/606 (GeoB 8083), 51.460 ${ }^{\circ} \mathrm{N}$, $11.700^{\circ} \mathrm{W}, 670 \mathrm{~m}$, seven shells, box corer, 01-XIII-2002; POS292/607 (GeoB 8084), 51.460 ${ }^{\circ} \mathrm{N}, 11.700^{\circ} \mathrm{W}, 670$ $\mathrm{m}$, two shells, box corer, 01-XIII-2002; POS400/GeoB 14548 (ROV5), $51.456^{\circ} \mathrm{N}, 11.707^{\circ} \mathrm{W}, 795-682 \mathrm{~m}$, multiple live specimens on rock, 11-VII-2010; Pollux Mound, POS400/GeoB 14526, 51.416 ${ }^{\circ} \mathrm{N}, 11.762^{\circ} \mathrm{W}, 905 \mathrm{~m}$, six shells, grab, 06-VII-2010; POS400/GeoB 14543 (ROV2), $51.335^{\circ} \mathrm{N}, 11.697^{\circ} \mathrm{W}, 847-723 \mathrm{~m}$, live individuals feeding on live Lophelia pertusa and on rocks with hydroids, 09-VII-2010; POS400/GeoB 14544 (ROV3), 51.339 ${ }^{\circ}$, $11.699^{\circ} \mathrm{W}, 793-818 \mathrm{~m}$, live individuals observed, 09-VII-2010.

Hovland Mound Province, Propeller Mound, POS265/497 (GeoB 6737), 52.156 ${ }^{\circ} \mathrm{N}, 12.768^{\circ} \mathrm{W}, 771 \mathrm{~m}$, one live specimen, dredge, 26-IX-2000; CARACOLE/PL126-4, 52.232 ${ }^{\circ} \mathrm{N}, 12.758^{\circ} \mathrm{W}, 670-869 \mathrm{~m}$, live individuals observed, 04-VIII-2001;

North Porcupine Bank, CARACOLE/PL129-7, $53.775^{\circ} \mathrm{N}, 13.971^{\circ} \mathrm{W}, 598-671 \mathrm{~m}$, live individuals observed, 08VIII-2001; PS64/282 (ROV), live individuals observed, $53.086^{\circ} \mathrm{N}, 14.806^{\circ} \mathrm{W}, 794 \mathrm{~m}, 12-\mathrm{VI}-2003$; Twin Mounds, PS64/283-3, 53.515 ${ }^{\circ} \mathrm{N}, 14.353^{\circ} \mathrm{W}, 966 \mathrm{~m}$, three shells, box corer, 13-VI-2003; PS64/297 (ROV), live individuals observed, $53.765^{\circ} \mathrm{N}, 13.992^{\circ} \mathrm{W}, 795 \mathrm{~m}, 15-\mathrm{VI}-2003$; Connaught Mound, M61-3/632 (GeoB 9285, ROV), 53.517 ${ }^{\circ}$, $14.367^{\circ} \mathrm{W}, 876 \mathrm{~m}$, live individuals observed, 15-VI-2004.

Rockall Bank, SE Rockall Bank, Logachev Mounds, Moundforce2004/37, 55.497 N, $15.802^{\circ} \mathrm{W}, 557 \mathrm{~m}$, five shells, box corer, 02-IX-2004 (Figs 21-24); HERMES2006/10C, $55.500^{\circ} \mathrm{N}, 15.799^{\circ} \mathrm{W}, 587 \mathrm{~m}$, two shells, box corer, 24-VI-2006; HERMES2006/12, 55.452 $\mathrm{N}, 15.766^{\circ} \mathrm{W}, 1091 \mathrm{~m}$, one shell, box corer, 24-VI-2006; HERMES2006/ $23 \mathrm{~A}, 55.500^{\circ} \mathrm{N}, 15.799^{\circ} \mathrm{W}, 587 \mathrm{~m}, 10$ shells, box corer, 26-VI-2006; HERMES2006/65, 55.452 ${ }^{\circ} \mathrm{N}, 15.766^{\circ} \mathrm{W}, 1087$ $\mathrm{m}$, five shells, box corer, 02-VII-2006; West Rockall Bank, Franken Mound, M61-3/603 (GeoB 9256), 56.503 ${ }^{\circ} \mathrm{N}$, $17.306^{\circ} \mathrm{W}, 629 \mathrm{~m}$, one live specimen, box corer, 11-VI-2004 (Figs 26-28); M61-3/628 (GeoB 9281, ROV), 56.498 ${ }^{\circ} \mathrm{N}$, $17.303^{\circ} \mathrm{W}, 651 \mathrm{~m}$, live individuals observed, 13-VI-2004; Kiel Seamount, POS316/499, 56.699 ${ }^{\circ} \mathrm{N}, 17.506^{\circ} \mathrm{W}, 824$ $\mathrm{m}$, one live specimen, box corer, 07-VIII-2004.

Hatton Bank, HERMES2008/117, $58.762^{\circ} \mathrm{N}, 18.757^{\circ} \mathrm{W}, 958 \mathrm{~m}$, one shell, video box corer, 06-VII-2008.

Azores, M151/69-1 (GeoB 23169), 37.659 $\mathrm{N}, 25.789^{\circ} \mathrm{W}, 595 \mathrm{~m}$, one shell, grab, 17-X-2018; M151/81 (GeoB 23181), $37.659^{\circ} \mathrm{N}, 25.789^{\circ} \mathrm{W}, 599 \mathrm{~m}$, one shell, box corer $19-\mathrm{X}-2018$.

Great Meteor Seamount, M151/110 (GeoB 23425-4), 29.565 ${ }^{\circ} \mathrm{N}, 28.339^{\circ} \mathrm{W}, 948 \mathrm{~m}$, one shell, ROV sample, $25-$ X-2018; M151/114 (GeoB 23429-5), 30.087 N, 28.727 W, 895 m, one shell, ROV sample, 26-X-2018; M151/114 (GeoB 23429-7), $30.086^{\circ} \mathrm{N}, 28.726^{\circ} \mathrm{W}, 902 \mathrm{~m}$, one shell, ROV sample, 26-X-2018.

Greece, Rhodes, St. Paul's Bay, Fossil - Mid Pleistocene, limestone outcrop (private collection A. Freiwald, Fig. 25). 

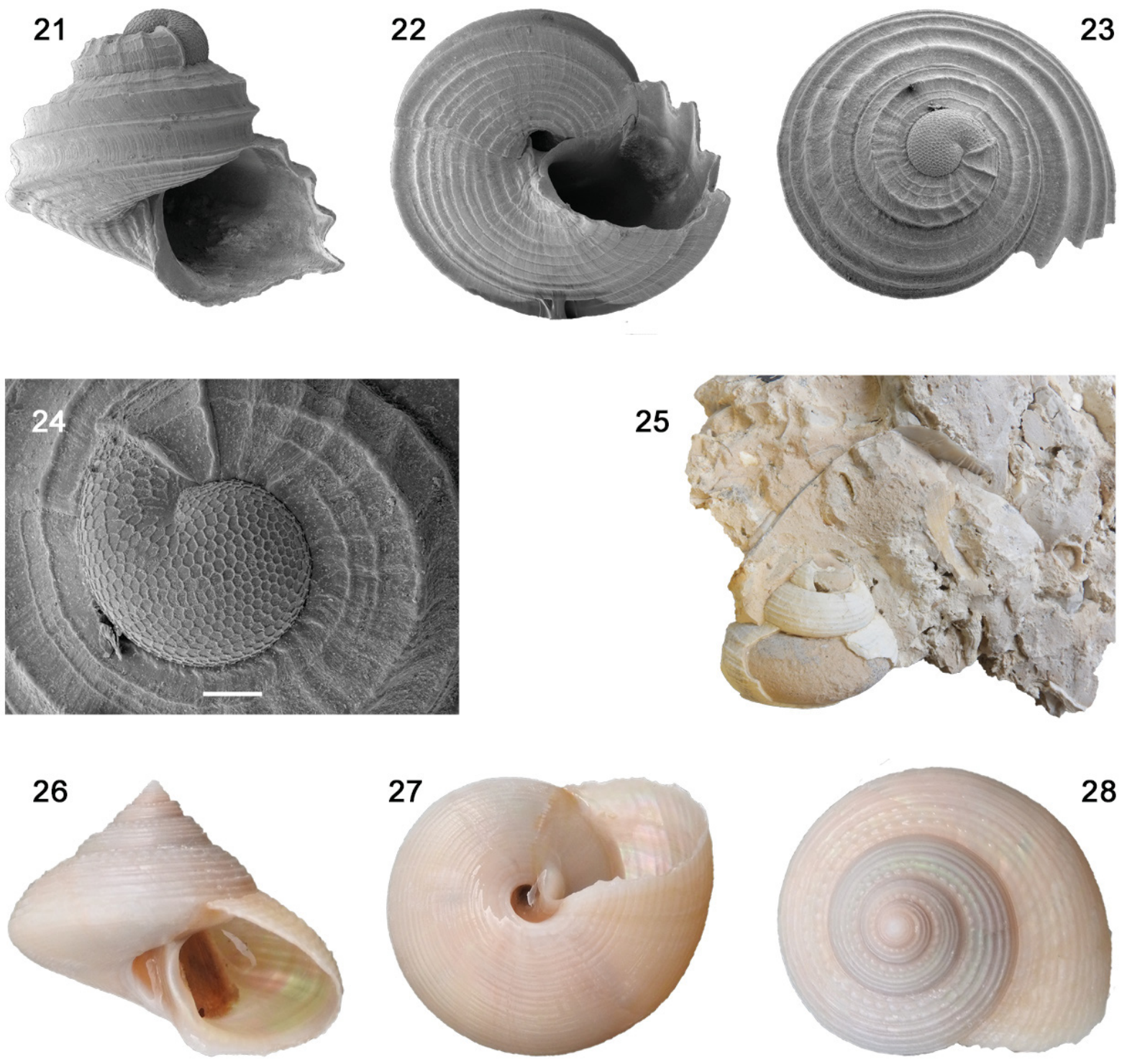

FIGURES 21-28. Calliostoma maurolici, 21-24. Moundforce2004/37, Juvenile specimen, H 1.4 mm, W 1.5 mm, protoconch W $0.48 \mathrm{~mm}$, T $0.36 \mathrm{~mm}$, scale bar $0.1 \mathrm{~mm}$. 25. Specimen from limestone outcrop, St. Paul's Bay, Rhodes, Mid-Pleistocene (private collection A. Freiwald). 26-28. M61-3/603, live-collected, H 16 mm, W 19 mm.

Description. We refer to the decriptions given by Seguenza (1876) and Locard (1898) and add details on the protoconch and the animal in the following.

The protoconch is similar to that of C. bullatum; 0.8 globular whorls ending with a rounded varix. The sculpture is hexagonally reticulated on a smooth background (Fig. 24). The hexagonal cells are arranged in about 15 spiral rows with a height of about $0.016 \mathrm{~mm}$ each.

The animal has an oblong snout with a swollen head with two long and pointed cephalic tentacles. Small black eyes on short ommatophores are present behind the base of the cephalic tentacles. A set of epipodial sensory tentacles is visible on the dorsal side of the foot below the shell. The living animal is pinkish white. The operculum is brown, translucent, thin, chitinous, spirally developed.

Distribution. Fossil in bathyal Early to Middle-Pleistocene formations in southern Italy (SW Calabria, NE Sicily) (G. Seguenza 1876; Barrier et al. 1996), Rhodes, Greece (own data) and on the Moroccan continental slope (Foubert 2007; Foubert et al. 2008). The fossil records from the Early Pleistocene suggest that the species has been living for about 2.5 million years. 
Our study includes recent specimens from the Porcupine Basin, Rockall Bank, Azores and Great Meteor Seamount in DWC, dead at 587-1087 m, alive at 598-1016 m (Fig. 1).

Locard (1898) reported syntypes of the synonymised Gibbula obesula off western Morocco (Talisman-188310, $717 \mathrm{~m}$ and Talisman-1883-71, $640 \mathrm{~m}$ ). Ibarrola et al. (2011) reported a live specimen in DWC off NW Spain. Reynell (1909) reported live specimens in the Bay of Biscay (Huxley-1906-7, 812 m, 24 live specimens and Huxley-1906-13, 753 m, one live specimen). These old records derive from samples rich in Lophelia pertusa and Madrepora oculata.
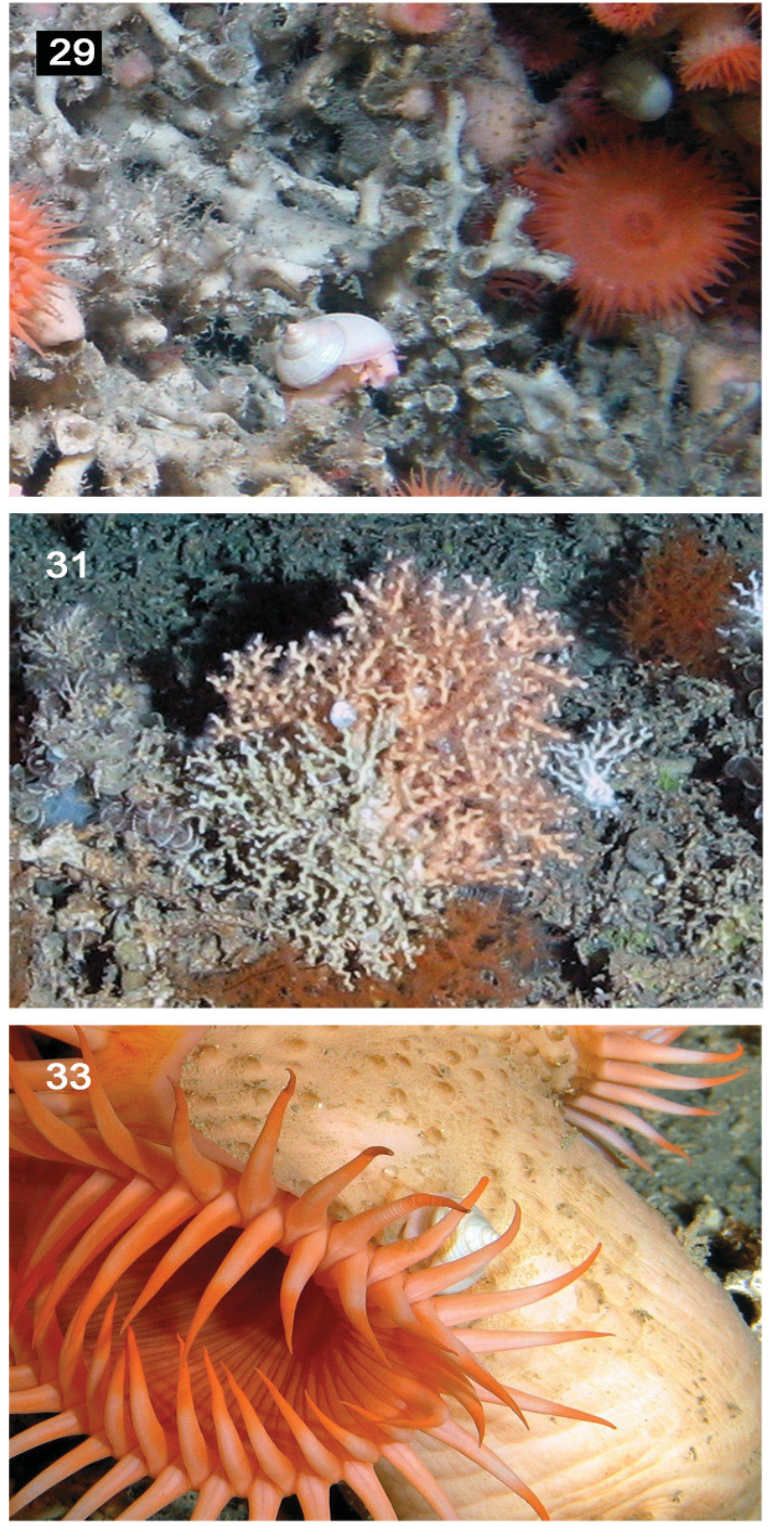
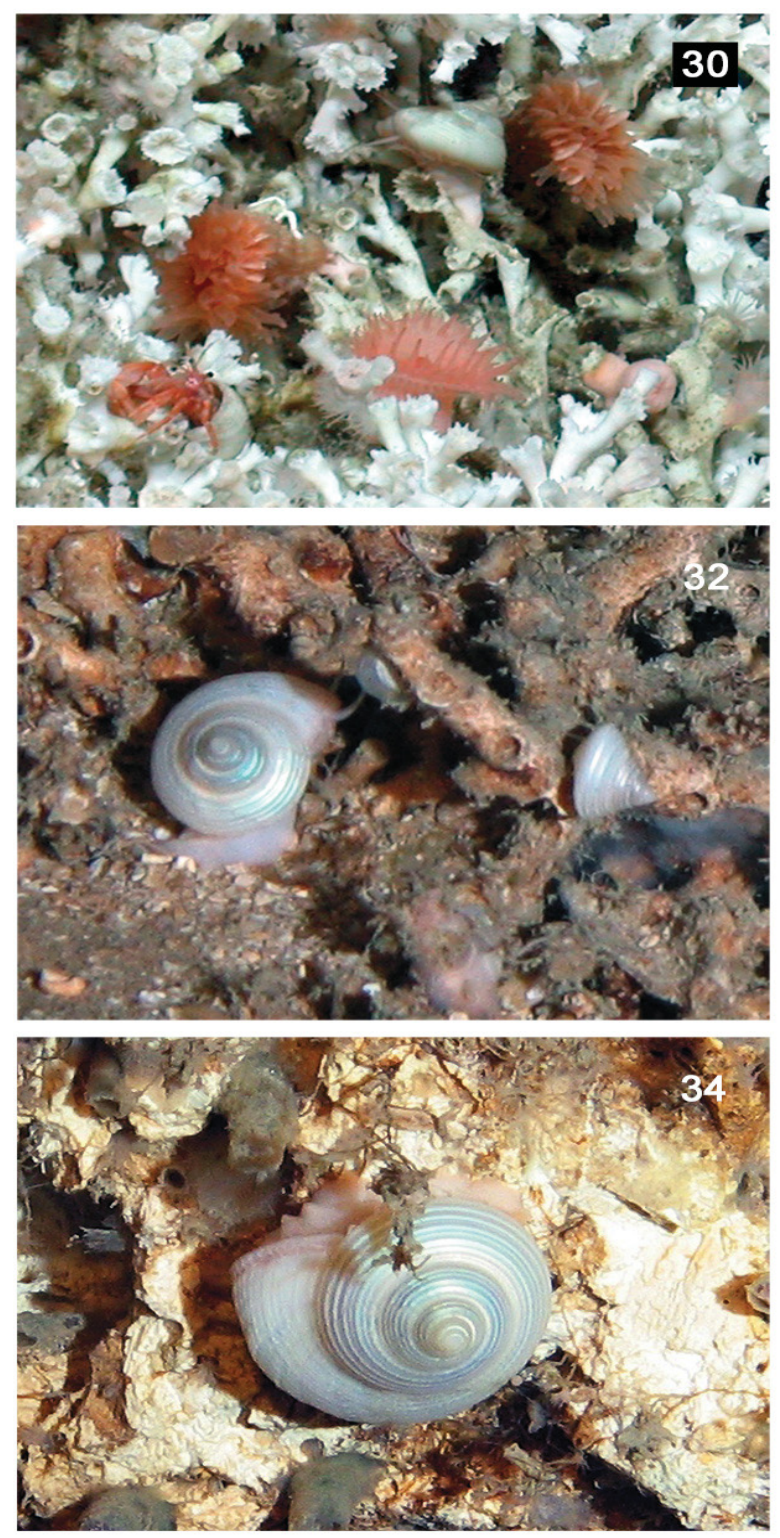

FIGURES 29-34. Calliostoma maurolici on various substrates. 29. Caracole/PL129-7 (ROV). Grazing on dead Lophelia pertusa framework. 30. M61-3/632 (GeoB 9285, ROV). Grazing on dead Lophelia pertusa framework portions. 31. POS 400/GeoB 14544 (ROV 3). Grazing on a Madrepora oculata colony. 32. POS400/GeoB 14548 (ROV5). Two specimens of different age grazing in close vicinity on dead coral framework. 33. POS400/GeoB 14543 (ROV2). Grazing on deep-sea anemone Phelliactis hertwigii. 34. POS400/GeoB 14548 (ROV5). Grazing on epiliths, grown on a hardground. [Fig. 29 was taken by ROV "VICTOR 6000”, IFREMER, France. Fig. 30 was taken by ROV “QUEST 4000” and Figs 31-34 were taken via ROV “Cherokee”, MARUM, Bremen University, Germany.] 
The species has a wide NE Atlantic distribution, associated with DWC, from the Rockall Bank in the north to the continental slope of Morocco in the south and the Azorean Seamounts in the west.

Remarks. Calliostoma maurolici is common in the NE Atlantic. The differences between the various Calliostoma species are given in the discussion of C. bullatum.

Our observations from ROV surveys found the species grazing on dead Scleractinia (Figs 29-30), live Madrepora oculata (Fig. 31), live Actiniaria (Phelliactis hertwigi Simon, 1892, Fig. 33) and on hardground with epiliths including hydroids (Figs 32,34). The animal is common in live Lophelia pertusa and Madrepora oculata communites in the Belgica Mound Province, SE of the Porcupine Bank (Freiwald \& Beck 2007; Beuck 2008; this paper).

\section{Calliostoma leptophyma Dautzenberg \& Fischer, 1896}

(Figs 35-43)

Calliostoma leptophyma Dautzenberg \& Fischer, 1896: 482 pl. 21 fig. 6

Type material. Not seen, unknown number, probably empty shell. Rocky ground west of Faial, Azores, PrincesseAlice-1895-77, at $845 \mathrm{~m}$. Scleractinians were also found at this location.

Material examined. Moroccan Slope, 64PE284/GeoB 12712, $35.368^{\circ} \mathrm{N}, 06.903^{\circ} \mathrm{W}, 685 \mathrm{~m}, 2$ shells in Pleistocene thanatocoenosis, grab, 23-II-2008.

Porcupine Basin, Belgica Mound Province, Castor Mound, M61-1/223, 51.430 ${ }^{\circ} \mathrm{N}, 11.794^{\circ} \mathrm{W}, 1029 \mathrm{~m}$, one shell, box corer, 23-IV-2004; Poseidon Mound, M61-3/577 (GeoB 9230), 51.452 ${ }^{\circ} \mathrm{N}, 11.747^{\circ} \mathrm{W}, 899 \mathrm{~m}$, nine shells, box corer, 7-VI-2004; Hovland Mound Province, Propeller Mound, POS292/562 (GeoB 8039), 52.137 ${ }^{\circ} \mathrm{N}, 12.768^{\circ} \mathrm{W}$, $850 \mathrm{~m}$, one shell, box corer, 25-VII-2002; North Porcupine Bank, Twin Mounds, PS64/283, 53.515 ${ }^{\circ} \mathrm{N}, 14.353^{\circ} \mathrm{W}$, $966 \mathrm{~m}$, two shells, box corer, 13-VI-2003.

Rockall Bank, Logachev Mounds, Moundforce2004/37, 55.497 N, $15.802^{\circ} \mathrm{W}, 557 \mathrm{~m}, 19$ shells, box corer, 02IX-2004 (Fig. 38); Moundforce2004/41C, $55.436^{\circ} \mathrm{N}, 16.116^{\circ} \mathrm{W}, 784 \mathrm{~m}$, three shells, box corer, 05-IX-2004 (Figs 41-44); HERMES2005/23, $55.503^{\circ} \mathrm{N}, 15.786^{\circ} \mathrm{W}, 167 \mathrm{~m}$, one shell, box corer, 27-VI-2005; HERMES2005/34, $55.445^{\circ} \mathrm{N}, 16.07^{\circ} \mathrm{W}, 767 \mathrm{~m}, 23$ shells, box corer, 28-VI-2005; HERMES2006/10C, $55.500^{\circ} \mathrm{N}, 15.799^{\circ} \mathrm{W}, 587 \mathrm{~m}$, seven shells, box corer, 24-VI-2006; HERMES2006/12, $55.452^{\circ} \mathrm{N}, 15.766^{\circ} \mathrm{W}, 1091 \mathrm{~m}$, one shell, box corer, 24-VI2006 (Figs 35-37); HERMES2006/23A, 55.500N, 15.799 ${ }^{\circ} \mathrm{W}, 587 \mathrm{~m}$, seven shells, box corer, 26-VI-2006 (Fig. 39); HERMES2006/28A, $55.498^{\circ} \mathrm{N}, 15.810^{\circ} \mathrm{W}, 588 \mathrm{~m}$, five shells, box corer, 27-VI-2006; HERMES2006/65, $55.452^{\circ} \mathrm{N}, 15.766^{\circ} \mathrm{W}, 1087 \mathrm{~m}$, one shell, box corer, 02-VII-2006.

Hatton Bank, HERMES2008/92, $58.734^{\circ} \mathrm{N}, 18.718^{\circ} \mathrm{W}, 822 \mathrm{~m}$, three shells, video box corer, 02-VII-2008.

Azores, M151/47 (GeoB 23147), 38.031 ${ }^{\circ} \mathrm{N}, 29.426^{\circ} \mathrm{W}, 830 \mathrm{~m}$, one shell, grab, 14-X-2018; M151/53-2 (GeoB 23153-2), $37.659^{\circ} \mathrm{N}, 25.789^{\circ} \mathrm{W}, 831 \mathrm{~m}$, one shell, grab, 15-X-2018; M151/69-2 (GeoB 23169-2), 37.659 ${ }^{\circ} \mathrm{N}$, $25.789^{\circ} \mathrm{W}, 898 \mathrm{~m}$, one shell, grab, 17-X-2018.

Atlantis Seamount, M151/89 (GeoB 23404), 33.971 ${ }^{\circ} \mathrm{N}, 30.206^{\circ} \mathrm{W}, 677 \mathrm{~m}$, one shell, grab, 21-X-2018.

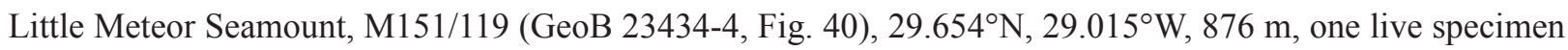
in Lophelia rubble, ROV sample, 27-X-2018.

Description. We refer to the description given by Dautzenberg \& Fischer (1896) and add details on the protoconch:

The protoconch is similar to that of $C$. bullatum, comprising 0.8 globular whorls with a rounded varix. Sculpture hexagonally reticulated on a smooth background (Fig. 37). Hexagonal cells loosely arranged in about 11 spiral rows and about 30 axial rows with a diameter of about $0.04 \mathrm{~mm}$ each; central pits round with a flat base.

Distribution. Calliostoma leptophyma is found from the Hatton, Rockall and Porcupine Banks in the north, the Azorean Seamounts in the west to the continental slope off Western Sahara in the south. Within this study, shells were found in the bathymetrical range of 557-1091 $\mathrm{m}$ and one live specimen at $876 \mathrm{~m}$. 

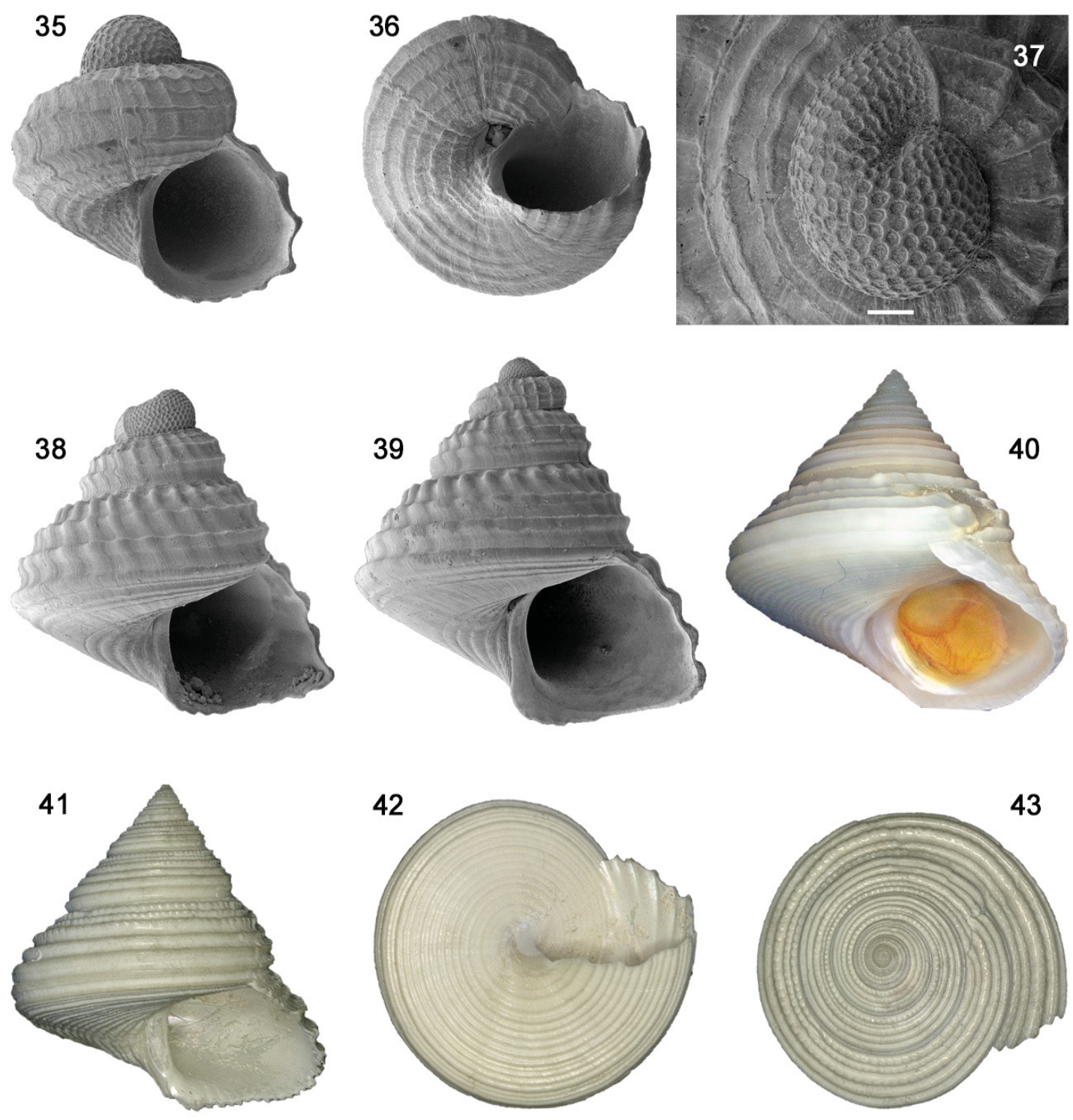

FIGURES 35-43. Calliostoma leptophyma. 35-37. HERMES2006/12, 35-36. H 1.0 mm, W 1.1 mm. 37. Protoconch W 0.59 mm, T $0.45 \mathrm{~mm}$, scale bar $0.1 \mathrm{~mm}$. 38. Moundforce2004/37, H $2.2 \mathrm{~mm}$, W $2.3 \mathrm{~mm}$, protoconch W $0.56 \mathrm{~mm}$, T $0.43 \mathrm{~mm} .39$. HERMES2006/23A, H 2.9 mm, W $2.9 \mathrm{~mm}$, protoconch W $0.57 \mathrm{~mm}$, T $0.43 \mathrm{~mm}$. 40. M151/GeoB 23434-4, live-collected, H 13 mm, W 14 mm. 41-43. Moundforce2004/41C, H 22 mm, W 23 mm.

Beck et al. (2003) reported shells from the Seine and Gettysburg Seamounts. Rolán \& Suárez (2007) mentioned three live specimens from the Galicia Bank at 769-1000 m and one live specimen off Cedeira, NW Spain at 600 $\mathrm{m}$. Le Duff (2015) mentioned two live specimens from the Bay of Biscay at 519-650 m. Locard (1898) reported specimens from off Western Sahara as Zizyphinus laquatus (Talisman1883/DR71, $640 \mathrm{~m}$ ) and Zizyphinus oppansus (Talisman1883/DR63, $640 \mathrm{~m}$ ).

Remarks. The frequent occurrence of Calliostoma leptophyma in coral rubble sampled at all DWC locations and one live specimen from the Little Meteor Seamount suggest a close association with DWC habitats. It displays a considerable morphological variability. A syntype of the synonymous Zizyphinus laquatus Locard 1898 from off Western Sahara (MNHN-IM-2000-31194) is very similar to the holotype but it has fewer spiral ribs with beads. A syntype of the synonymous Zizyphinus oppansus Locard, 1898 from off Western Sahara (MNHN-IM-2000-31252) has a nearly smooth and flat base with a strong keel on the body whorl. In contrast, the holotype has a more rounded outline and flattened spiral ribs on the base of the body whorl. 
The differences between the various Calliostoma species have been discussed above (C. bullatum).

Two syntypes of $C$. cleopatra have been described from off Western Sahara at 1435 m (MNHN-IM-200031095); this species is more slender and has regularly spaced spiral ribs on the upper whorl face, on the wellrounded periphery and on the base. Moreover, it has more pronounced beads on the spiral ribs. Future physiological and molecular studies may prove this species to be synonymous with $C$. leptophyma. Specimens reported under the name C. cleopatra (Locard, 1898) by Hoffman et al. (2011) are considered to represent C. leptophyma herein.

\section{Discussion}

Calliostoma bullatum and Calliostoma maurolici were found alive on Lophelia pertusa and Madrepora oculata, partly with visual grazing traces on the frameworks. The oldest records of these calliostomatids are from the Early Pleistocene, co-occurring with DWCs in the Mediterranean (Barrier et al. 1996; La Perna \& Abramo 2010).

Calliostoma maurolici and C. leptophyma have a wide distribution range from the Rockall Bank in the north to off NW Africa in the south and the Azorean Seamounts in the west. They are unknown from the Mauritanian slope.

Calliostoma bullatum is the only species known to live in DWC habitats on the Mauritanian slope. The current live population is separated from its original distribution during the Early Pleistocene that included the Mediterranean Sea. Mollusc species living since the Pleistocene are not uncommon. However, C. bullatum is the second rediscovery of a living mollusc from off Mauritania that has been surviving since the Pleistocene; the other species is Fissurisepta papillosa G. Seguenza, 1863 (Hoffman \& Freiwald 2018).

The deep-sea fauna of the Mediterranean Sea has been subject to massive changes during the Messinian Salinity Crisis (7.15 Ma) when the Gibraltar gap started closing and water influx was limited (e.g. Freiwald 2019). The fauna was largely wiped out during the subsequent evaporation phases (Pérès 1985; Vertino et al. 2014; Freiwald 2019). When the Gibraltar gap opened up again at 5.33 Ma the Mediterranean Sea was repopulated with Atlantic fauna within a short period of time (Di Geronimo et al. 2005; Vertino et al. 2014).

A period of global cooling developed towards the end of the Pliocene and Early Pleistocene. Deep-water corals and associated fauna including Calliostoma bullatum and C. maurolici are part of the Early Pleistocene fauna and the outcrops near Messina date from this period. It was followed by a sequence of ice ages with short intermediate periods of warming. During the last glaciation period (Würmian, $115-11.7 \mathrm{Ka}$ ), the sea level fell by some $120 \mathrm{~m}$ causing the water exchange at Gibraltar to diminish. Boreal species settled in the upper shelf areas of the western Mediterranean Sea but the deep-water fauna was largely impoverished. The gap at Gibraltar is narrowing again since the Late Pleistocene and water circulation in the Mediterranean Sea is decreasing, causing homothermic conditions in deep water. Mean annual water temperature in the deep of the Mediterranean Sea has risen to more than $13^{\circ} \mathrm{C}$ at present which causes the Palaeo-Atlantic cold-water fauna to perish (see for example Pérès (1985) on various taxa, Di Geronimo \& La Perna (1997) on Mollusca, and Vertino et al. (2014) on scleractinians). The shallow gap at Gibraltar also forms a barrier to deep-water larvae, which complicates repopulation of Mediterranean deep-water habitats from the Atlantic Ocean. Migration of the DWC fauna from the Atlantic to the Mediterranean is further restricted because the massive Atlantic DWC communities have moved north with its current-day culmination off western Norway (Frank et al. 2011). There are few thriving DWC communities on the NW African Slope, off the Iberian Peninsula and in the Mediterranean Sea. They are limited in size and scattered along the continental slopes. The DWC-associated calliostomatids are probably extinct in the Mediterranean Sea even though DWC colonies are still living locally (Vertino et al. 2014). The calliostomatids in the scattered DWC communities in the NE Atlantic south of the Porcupine, Rockall and Hatton Basins are considered survivors ("last snails standing") since the Early Pleistocene.

\section{Acknowledgements}

Crews and scientific staffs of R/V l'Atalante, R/V Maria S. Merian, R/V Meteor, R/V Pelagia, R/V Polarstern, R/V Poseidon, and R/V Victor Hensen are acknowledged for their dedication in collecting the sediment samples. We thank Tomas Lundälv from the Sven Lovén Centre for Marine Infrastructure Tjärnö, Strömstad, Sweden, for profes- 
sionally operating the ROV "Sperre" during the cruise MSM16-3 and MARUM, Bremen University, Germany, professionally operating the ROV "Cherokee" during cruise POS400 and ROV "QUEST 4000" during cruise M61-3. We are grateful to IFREMER, Plouzané, France for their permission to use ROV "VICTOR 6000" images from the CARACOLE cruise. These ROV data yielded high quality footage that enabled species identification. Nicol Mahnken is acknowledged for technical assistance in preparing SEM samples and for maintaining the cruise material. We thank Rafael La Perna, Bruce Marshall and the editors for their constructive critique and for improving this paper.

\section{References}

Barrier, P., Di Geronimo, I., La Perna, R., Rosso, A., Sanfilippo, R. \& Zibrowius, H. (1996) Taphonomy of deep-sea hard and soft bottom communities: the Pleistocene of Lazzaro (Southern Italy). Communicacion de la II reunion de tafonomia y fossilizacion, 1996, 39-46.

Beck, T., Metzger, T. \& Freiwald, A. (2003) BIAS, Biodiversity Inventorial Atlas of Macrobenthic Seamount Animals. OASIS, University of Hamburg, Hamburg, 118 pp.

Beuck, L. (2008) Framework-building cold-water coral ecosystem characterisation: Key studies from macro- to microfauna. Dissertation Friedrich-Alexander University, Erlangen-Nuremberg, 189 pp.

Born, I. von (1778) Index rerum naturalium Musei Caesarei Vindobonensis. Pars I.ma. Testacea. Verzeichniß der natürlichen Seltenheiten des $k$. $k$. Naturalien Cabinets zu Wien. Erster Theil. Schalthiere. ex officina Krausiana, Vindobonae, $40+458$ $+82 \mathrm{pp}$.

Bruyne, R. de, Leeuwen, S. van, Gmelig Meyling, A. \& Daan, R. (2013) Schelpdieren van het Nederlandse Noordzeegebied. Ecologische atlas van de mariene weekdieren (Mollusca). Publisher Tirion, Utrecht and Foundation Anemoon, Lisse, 414 pp.

Buhl-Mortensen, L., Vanreusel, A., Gooday, A.J., Levin, L.A., Priede, I.G., Buhl-Mortensen, P., Gheerardyn, H., King, N.J. \& Raes, M. (2010) Biological structures as a source of habitat heterogeneity and biodiversity on the deep ocean margins. Marine Ecology, 31 (1), 21-50. [ISSN 0173-9565] https://doi.org/10.1111/j.1439-0485.2010.00359.x

Chagnoux, S. (2017) The molluscs collection (IM) of the Muséum national d'Histoire naturelle (MNHN, Paris). Version 70.24. MNHN, Museum national d'Histoire naturelle. URL Occurrence Dataset. https://doi.org/10.15468/xgoxap

Coen, G. (1933) Saggio di una Sylloge Molluscorum Adriaticorum. Memorie del Regio Comitato Talassografico Italiano, 192, I-VII + 1-186.

Cossignani, T. \& Ardovini, R. (2011) Malacologia Mediterranea. L’Informatore Piceno, Ancona, 536 pp.

Dautzenberg, P. (1927) Mollusques provenant des campagnes scientifiques du Prince Albert Ier de Monaco dans l'Océan Atlantique et dans le Golfe de Gascogne. Résultats des Campagnes Scientifiques Accomplies sur son Yacht par Albert Ier Prince Souverain de Monaco, LXXII. Imprimerie de Monaco, Monaco, 401 pp., 9 pls.

Dautzenberg, P. \& Fischer, H. (1896) Dragages effectués par l'Hirondelle et par la Princesse Alice 1888-1895. 1. Mollusques Gastropodes. Mémoires de la Société Zoologique de France, 9, 395-498, pls. 15-22.

Dautzenberg, P. \& Fischer, H. (1897) Dragages effectués par l'Hirondelle et par la Princesse Alice 1888-1896. Mémoires de la Société Zoologique de France, 10, 139-234; pls 3-7.

Dornellas, A.P.S. \& Simone, L.R.L. (2011) Bivalves in the stomach contents of Calliostoma coppingeri (Callistomatidae: Gastropoda). Strombus, 18 (1-2), 1-14.

Duineveld, G.C.A. (Ed.) (2006) Biodiversity, ecosystem functioning and food web complexity of cold water coral reefs in the NE Atlantic (Rockall Bank). Cruise 64PE249, Galway-Oban 19 June-7 July 2006. NIOZ, Texel, 25 pp.

Ferro, R. \& Cretella, M. (1993) Osservazioni sulla biologia di Calliostoma granulatum (Born) (Gastropoda: Trochidae). Bollettino Malacologico, 29 (1-4), 49-56.

Foubert, A. (2007) Nature and significance of the carbonate mound record: The Mound Challenger Code. Dissertation Renard Centre of Marine Geology, Department of Geology and Soil Sciences, Ghent University, Ghent, 341 pp.

Foubert, A., Depreiter, A., Beck, T., Maignien, L., Pannemans, B., Frank, N., Blamart, D. \& Henriet, J-P. (2008) Carbonate mounds in a mud volcano province off north-west Morocco: Key to processes and controls. Marine Geology, 248, 74-96. https://doi.org/10.1016/j.margeo.2007.10.012

Frank, N. [editor] (2018) Short Cruise Report, M151, Atlantic Thermocline Ocean and Ecosystems Dynamic during Natural Climate Change. Institut für Umweltphysik, Universität Heidelberg, Heidelberg, 15 pp.

Frank, N., Freiwald, A., López Correa, M., Wienberg, C., Eisele, M., Hebbeln, D., van Rooij, D., Henriet, J.P., Colin, C., van Weering, T., De Haas, H., Buhl-Mortensen, P., Roberts, J.M., De Mol, B., Douville, E., Blamart, D. \& Hatte, C. (2011) Northeastern Atlantic cold water coral reefs and climate. Geology, 39, 743-746.

https://doi.org/10.1130/G31825.1

Freiwald, A. (Ed.) (2002) ACES, Cruise Report, RV Poseidon Cruise 292, Reykjavik-Galway, 15 July-4 August 2002. University of Erlangen, Erlangen, $86 \mathrm{pp}$.

Freiwald, A. (2019) Messinian Salinity Crisis: what happened to CWCs? In: Orejas, C. \& Jiménez, C. (Eds.), Mediterranean 
cold-water corals: Past, present and future. Springer International Publishing, Basel, pp. 47-50.

Freiwald, A. \& Dullo, C. (Eds.) (2000) Cruise report, RV Poseidon Cruise 265, Thòrshavn, Galway, Kiel, 13 September-1 October 2000. Tübingen University \& GEOMAR, Kiel, 57 pp.

Freiwald, A. \& Beck, T. (2007) Forcing of carbonate mounds and deep-water coral reefs along the NW European continental margin. MOUNDFORCE Final Report, Institute of Paleontology, University of Erlangen-Nuremberg, Erlangen, 39 pp.

Freiwald, A. \& Henrich, R. (1997) Victor Hensen Cruise VH-97 Leg 1 and Leg 5. Unpublished report and station list, Institut für Paläontologie, Universität Erlangen, Erlangen, $24+8$ pp.

Fretter, V. \& Graham, A. (1977) The Prosobranch Molluscs of Britain and Denmark. Part 2. Trochacea. Journal of Molluscan Studies, Supplement 3, 39-100.

Geronimo, I. di \& La Perna, R. (1997) Pleistocene bathyal molluscan assemblages from southern Italy. Rivista Italiana di Paleontologia e Stratigrafia, 103 (3), 389-426.

Geronimo, I. di, Messina C., Rosso A., Sanfilippo, R., Sciuto, F. \& Vertino, A. (2005) Enhanced biodiversity in the deep: Early Pleistocene coral communities from southern Italy. In: Freiwald, A. \& Roberts, J.M. (Eds.), Cold-water Corals and Ecosystems. Springer-Verlag, Berlin and Heidelberg, pp. 61-86. https://doi.org/10.1007/3-540-27673-4_4

Göcke, C., Hestetun, J.T., Uhlir, C., Freiwald, A., Beuck, L. \& Janussen, D. (2016) Cladorhiza corallophila sp. nov., a new carnivorous sponge (Cladorhizidae, Demospongiae) living in close association with Lophelia pertusa and Madrepora oculata (Scleractinia). Zootaxa, 4168 (3), 512-524. https://doi.org/10.11646/zootaxa.4168.3.4

Harasewych, M.G. \& Sedberry, G.R. (2006) Rediscovery, range extension, and redescription of Calliostoma torrei Clench and Aguayo 1940 (Gastropoda: Vetigastropoda: Calliostomatidae). The Nautilus, 120 (2), 39-44.

Hebbeln, D., Wienberg, C., Beuck, L., Boom, L., Cunha, M., Dimmler, W., Eisele, M., El Frihmat, Y., Fink, H., Groenewegen, R., Löffler, S.-B., López, N., Lutz, M., Meyer-Schack, B. \& Nowald, N. (2008) Report and preliminary results of RV Pelagia Cruise 64PE284. Cold-water Corals in the Gulf of Cádiz and on Coral Patch Seamount (NE Atlantic). PortimãoPortimão, 18.02.-09.03.2008. Berichte, Fachbereich Geowissenschaften, Universität Bremen, No. 265, 1-90.

Hoffman, L. \& Freiwald, A. (2018) Last snails standing since the Pleistocene, a tale of Fissurellidae (Gastropoda) from deepwater coral habitats off Mauritania. Miscellanea Malacologica, 7 (6), 102-114.

Hoffman, L., van Heugten, B. \& Lavaleye, M.S.S. (2011) Gastropoda (Mollusca) from the Rockall and Hatton Banks, northeastern Atlantic Ocean. Part 2. Miscellanea Malacologica, 4 (6), 85-118.

Ibarrola, T.P., Rolán, E. \& Lopez, P.R. (2011) Nueva informacion sobre Calliostoma obesulum (Archaeogastropoda, Calliostomatidae) procedente del canon de Aviles, $\mathrm{N}$ de la peninsula Iberica. Noticiario SEM, 56, 44-49.

La Perna, R. \& D’Abramo, M. (2010) Una collezione di G. Seguenza conservata presso l'Istituto Tecnico Commerciale “O.G. Costa" di Lecce. Bollettino Malacologica, 46, 29-35.

Lavaleye, M. (Ed.) (2008) HERMES 2008 CoralFISH2008, Belgica Mound Province, Hatton Bank. Cruise Report 64PE291292, Texel-Cork-Texel, 10 June-16 July 2008. NIOZ, Texel, 90 pp.

Le Duff, M. (2015) Contribution to the knowledge of the geographic and bathymetric distribution of Calliostoma leptophyma (Dautzenberg \& H. Fischer, 1896) (Gastropoda, Calliostomatidae). Les cahiers naturalistes de l'Observatoire marin, 4 , $25-28$

Linnaeus, C. (1758) Systema Naturae per regna tria naturae, secundum classes, ordines, genera, species, cum characteribus, differentiis, synonymis, locis. Editio decima, reformata. Laurentius Salvius, Holmiae, ii + 824 pp. https://doi.org/10.5962/bhl.title.542

Locard, A. (1898) Mollusques testacés. Expeditions Scientifiques du "Travailleur" et du "Talisman" pendant les années 1880 , 1881, 1882, 1883. Vol. 1. Editor Masson \& Cie, Paris, 512 pp.

Marshall, B.A. (1995a) A Revision of the Recent Calliostoma Species of New Zealand (Mollusca: Gastropoda: Trochoidea). The Nautilus, 108 (4), 83-127.

Marshall, B.A. (1995b) Calliostomatidae (Gastropoda: Trochoidea) from New Caledonia, the Loyalty Islands, and the northern Lord Howe Rise. Résultats des Campagnes Musorstom 14. Mémoires de la Muséum National d'Histoire Naturelle, 167, 381-458.

Micali, P. \& Villari, A. (1989) Le specie malacologiche de Salice (Messina), Instituite da Guiseppe Seguenza. Accademia Peloritana dei Pericolanti Classe di Scienze Fisiche, Matematiche e Naturali, 67 (Supplement 1), 345-363.

Mighels, J.W. \& Adams, C.B. (1842) Descriptions of twenty-four new species of New England shells. Boston Journal of Natural History, 4, 37-54, pl. 4

Olu-Le Roy, K., Caprais, J.-C., Crassous, P., Dejonghe, E., Eardley, D., Freiwald, A., Galeron, J., Grehan, A., Henriet, J-P., Huvenne, V., Lorance, P., Noel, P., Opderbecke, J., Pitout, C., Sibuet, M., Unnithan, V., Vacelet, J., Van Weering, T., Wheeler, A. \& Zibrowius, H. (2002) CARACOLE Cruise Report. 30/07/2001 (Cobh)—15/08/2001 (Foynes) N/O L'Atalante \& ROV VICTOR. Vols. $1 \&$ 2. Unpublished Report, IFREMER, Brest. Station list available. Available from: http://www.ifremer. fr/biocean/acces_gb/rapports/Appel_2cruisefr.htql?numcruise=100_(accessed 2 July 2018)

Pérès, J.M. (1985) Chapter 7. History of the Mediterranean biota and the colonization of the depths. In: Margalef, R. (Ed.), Western Mediterranean. Pergamon Press, Oxford, pp. 198-232.

Perron, F.E. \& Turner, R.D. (1978) The feeding behaviour and diet of Calliostoma occidentale, a coelenterate-associated prosobranch gastropod. Journal of Molluscan Studies, 44, 100-103. 
Pfannkuche, O., Bannert, B., Beck, T., Beuck, L., Dullo, W.-C., Flögel, S., Freiwald, A., Gass, S., Gektidis, M., Heger, A., Jamieson, A., Kavanagh, F., King, N., Kuhanec, B., Linke, P., Martin, B., Neulinger, S., Noe, S., Queisser, W., Rüggeberg, A., Ruseler, S., Schiemer, I., Schmidt, S., Schönfeld, J., Taviani, M., Türk, M., Vertino, A. \& Wigham, B. (2004) Geo-Biological Investigations on Azooxanthellate Cold-Water Coral Reefs on the Carbonate Mounds along the Celtic Continental Slope. Meteor Cruise M61 Leg 1, Lisbon-Cork, 19.04.-04.05.2004, 1-69.

Pfannkuche, O. \& Utecht, C. [editors] (2005) Carbonate Mounds and Aphotic Corals in the NE-Atlantic. FS Poseidon Fahrtbericht / Cruise Report POS 316, Reykjavik-Lissabon, 03.08.-17.08.2004. IFM-GEOMAR, Leibniz-Institut für Meereswissenschaften an der Universität, Kiel, 63 pp.

Philippi, R.A. (1844) Enumeratio Molluscorum Siciliae. Vol. 2. Eduardi Anton, Halis Saxonum, 304 pp. https://doi.org/10.5962/bhl.title.100735

Quinn, J.F. Jr. (1981) The gastropods, Calliostoma orion Dall, 1889 (Trochidae) and Heliocus (Gyriscus) worsfoldi n. sp. (Architectonicidae), from the Bahama Islands. The Nautilus, 95 (3), 150-156.

Ramos, A., Sanz, J.L., Ramil, F., Agudo, L.M. \& Presas-Navarro, C. (2017) The Giant Cold-Water Coral Mounds Barrier Off Mauritania. In: Ramos, A., Ramil, F. \& Sanz, J.L. (Eds.), Deep-Sea Ecosystems Off Mauritania: Research of Marine Biodiversity and Habitats in the Northwest African Margin, 2017, pp. 481-525. https://doi.org/10.1007/978-94-024-1023-5

Ratmeyer, V., Beck, T., Belling, R., Bergenthal, M., Beuck, L., Brakel, C., Buhmann, S., Dodds, L., Dorschel, B., Engemann, G., Foubert, A., Gault, J., Grehan, A., Hayn, C., Jurkiw, A., Kahl, G., Kaiser, J., Klar, S., Lutz, M., Noe, S., Papstein, H., Rüggeberg, A., Ruhland, G., Schewe, F.. Schmidt, W., Schröder, M., Seiter, C., Truscheit, T. \& Wienberg, C. (2004) Development of Carbonate Mounds on the Celtic Continental Margin. METEOR Cruise M61, Northeast Atlantic 2004, Leg 3, Cork-Ponta Delgada, 4th June-26th June 2004, 1-45.

Reynell, A. (1909) The Mollusca collected by the "Huxley" from the North Side of the Bay of Biscay, in August 1906. Journal of the Marine Biological Association of the United Kingdom, 8, 359-391. https://doi.org/10.1017/S0025315400073641

Roberts, J. M., Wheeler, A.T. \& Freiwald, A. (2006) Reefs of the Deep: The Biology and Geology of Cold-Water Coral Ecosystems. Science, 312 (5773), 543-547. https://doi.org/10.1126/science.1119861

Rolán, E. \& Suárez, M. (2007) Primera cita de Calliostoma leptophyma (Mollusca, Calliostomatidae) para aguas de la Península Ibérica. Noticiario SEM, 47, 39-43.

Rogers, A.D. (1999) The Biology of Lophelia pertusa (Linnaeus 1758) and Other Deep-Water Reef-Forming Corals and Impacts from Human Activities. International Review of Hydrobiology, 84 (4), 315-406. https://doi.org/10.1002/iroh.199900032

Seguenza, G. (1863) Paleontologia malacologica delle rocce terziarie del distretto di Messina studiata nei suoi rapporto zoologici e geognostici. Annali dell'Accademia degli Aspiranti Naturalisti, Napoli, 3 (2), 2-77.

Seguenza, G. (1876) Studi stratigrafici sulla formazione pliocenica dell'Italia meridionale. Bollettino, Reale Comitato Geologico d'Italia, Roma, 7, 179-189.

Seguenza, L. (1903) Molluschi poco noti dei terreni Terziari di Messina-Trochidae e Solaridae. Bollettino. Societa Geologica Italia, Roma, 21 (fase. 3), 455-464, tav. XVII.

Simon, J.A. (1892) Ein Beitrag zur Anatomie und Systematik der Hexactinien. Druck von Val. Höfling, München, 102 pp.

Swainson, W. (1840) A treatise on malacology or shells and shell-fish. Longman, London, viii +419 pp.

Thiede, J. (Ed.) (2003) Cruise report ARK-XIX-3a (PS64). Brest-Galway 02.06.2003-20.06.2003. Berichte Polarforschung Meeresforschung, Alfred Wegener Institut, Bremerhaven, $356 \mathrm{pp}$.

Thiele, J. (1924) Revision des Systems der Trochacea. Mitteilungen aus dem Zoologischen Museum in Berlin, 11, 47-74, 1 pl. https://doi.org/10.1002/mmnz.4830110104

Vertino, A., Stolarski, J., Bosellini, F.R. \& Taviani, M. (2014) Mediterranean Corals Through Time: From Miocene to Present. In: Goffredo, S. \& Dubinsky, Z. (Eds.), The Mediterranean Sea: Its history and present challenges, Paper 14, pp. $257-274$. https://doi.org/10.1007/978-94-007-6704-1 14,

Westphal, H., Beuck, L., Braun, S., Freiwald, A., Hanebuth, T., Hetzinger, S., Klicpera, A., Kudrass, H., Lantzsch, H., Lundälv, T., Vicens, G.M., Preto, N., Reumont, J. van, Schilling, S., Taviani, M. \& Wienberg, C. (2014) Phaeton, Paleoceanographic and paleo-climatic record on the Mauritanian Shelf, Cruise No. MSM16/3, Bremerhaven (Germany) - Mindelo (Cap Verde), 13 October-20 November, 2010, Maria S. Merian-Berichte, 1-57.

Westphal, H. [editor] (2007) MACUMA Integrating carbonates, siliciclastics and deep-water reefs for understanding a complex environment. Poseidon 346 cruise report, Las Palmas—Las Palmas, 28.12.2006-15.1.2007, 40 pp.

Wheeler, A.J., Beyer, A., Freiwald, A., Haas, H. de, Huvenne, V., Kozachenko, M., Olu-Le Roy, K. \& Opderbecke, J. (2007) Morphology and environment of cold-water coral carbonate mounds on the NW European margin. International Journal of Earth Sciences, 96 (1), 37-56. https://doi.org/10.1007/s00531-006-0130-6.

Wienberg, C., Beuck, L., Coughlan, M., Dimmler, W., Eisele, M., Freiwald, A., Klann, M., Ruhland, G. \& Stone, J. (2010) CORICON-Cold-water corals along the Irish continental margin. Report and preliminary results of RV Poseidon Cruise 
POS400, Vigo-Cork, June 29-July 15 2010. Berichte aus dem Fachbereich Geowissenschaften der Universität Bremen, 275, 1-46.

Williams, S.T., Karube, S. \& Ozawa, T. (2008) Molecular systematics of Vetigastropoda: Trochidae, Turbinidae and Trochoidea redefined. Zoologica Scripta, 37, 483-506. https://doi.org/10.1111/j.1463-6409.2008.00341.x

Williams, S.T., Donald, K.M., Spencer, H.G. \& Nakano, T. (2010) Molecular systematics of the marine gastropod families Trochidae and Calliostomatidae (Mollusca: Superfamily Trochoidea). Molecular Phylogenetics and Evolution, 54, $783-809$. https://doi.org/10.1016/j.ympev.2009.11.008

Williams, S.T. (2012) Advances in molecular systematics of the vetigastropod superfamily Trochoidea. Zoologica Scripta, 41 , 571-595.

https://doi.org/10.1111/j.1463-6409.2012.00552.x 